\title{
Latency Through Uncertainty: the 1994 Matsumoto Sarin Incident as a Delayed Cultural Trauma
}

\author{
Rin Ushiyama ${ }^{1}$ (iD \\ Published online: 5 March 2018 \\ (C) The Author(s) 2018. This article is an open access publication
}

\begin{abstract}
Cultural trauma theory has emphasised the role of social groups in narrating, and thereby attributing moral significance to, highly disruptive events. In contrast, this article draws attention to professions such as the police and the media, which act as "fact-finders" to establish the factual circumstances of events from which trauma narratives are created. The article offers a case study of the June 1994 Matsumoto Sarin Incident in Japan, a terrorist attack in which members of religious movement Aum Shinrikyō gassed residential streets using sarin. Factual uncertainties surrounding the attack, in combination with institutional failings by fact-finders that resulted in a false accusation, meant that carrier groups did not identify the event as one that brought a collectivity's underlying values into question; in other words, cultural trauma as a discourse did not develop. It was only after Aum's second sarin attack on the Tokyo subway in March 1995, when the true perpetrators and motives were finally uncovered, that Matsumoto belatedly became recognised as a traumatic assault on Japan's civic values. This article suggests that a collaborative approach combining science and technology studies (STS) with collective memory studies could provide a fruitful avenue of further research.
\end{abstract}

Keywords Aum Affair · Aum Shinrikyo $\cdot$ Japan · Memory · Police $\cdot$ Journalism

The aim of this paper is to refine cultural trauma theory through a consideration of social groups responsible for establishing the factual details of highly disruptive events. The theory of cultural trauma states that certain events acquire a negative, indelible quality in a group's collective identity and memory when there is a sense of "acute discomfort entering into the core of the collectivity's sense of its own identity" (Alexander 2004b: 10). Cultural trauma explicitly rejects "naturalistic" theories of group trauma-which suggests that entire

Marcus Morgan (Bristol University) was Acting Editor for this article.

Rin Ushiyama

ru210@cam.ac.uk

1 Department of Sociology, University of Cambridge, 16 Mill Lane, Cambridge CB2 1SB, UK 
collectivities are automatically traumatised by devastating events - and advocates a systematic study of the social conditions which make public articulations of group-level trauma possible. By offering a constructionist approach to how some events become watershed moments in collective memory but not others, cultural trauma theory has produced an array of historical examples in which public expressions of trauma were delayed or repressed, due to the sheer scale of the devastation (Alexander 2004a), political censorship and discrimination of victims (Saito 2006), or dominant ideologies suppressing alternative interpretations of past violence (Bartmanski and Eyerman 2011; Gao 2011). While sympathetic to these innovations, this article offers a slightly different approach to explain the absence of cultural trauma discourse. While existing studies have tended to explain the absence of trauma discourse to be the result of material constraints (such as low economic capital or censorship), the aftermath of the Matsumoto Sarin Incident provides an example in which trauma construction faltered due to failures in forensics and related investigative procedures, leading to factual uncertainty. This article presents a reconstruction of media coverage surrounding two terrorist attacks committed by the millenarian new religious movement Aum Shinrikyō: the June 1994 Matsumoto Sarin Incident and the March 1995 Tokyo Subway Sarin Incident, both of which attacked civilians using deadly sarin gas. Following the Matsumoto attack on June 1994, missteps in police investigation and news reporting meant that potential "carrier groups" of trauma failed to correctly identify perpetrators and their motives throughout 1994 and therefore struggled to narrate the event as a cultural trauma. Aum's attack on Tokyo in the following year enabled investigators to discover the culprits and their motives, allowing stakeholders to put forward trauma narratives about the Matsumoto attack, albeit with a significant period of latency and also subsumed within a broader label of a greater national trauma known as the "Aum Affair".

\section{Cultural Trauma and the "Trauma Process"}

Cultural trauma's most distinctive feature is its fundamental rejection of the idea that grouplevel trauma is a natural consequence of devastating events. Whereas Kai Erikson's (1976) concept of "collective trauma" refers to the breakdown of social solidarity and community identity as a "natural" and automatic consequence of communities devastated by disaster, cultural trauma insists that events become recognised as traumatic in collective identity through symbolic mediation, such as media reports, witness testimonies, artistic works, and films and television. Cultural trauma describes not so much a collective state of being, but "processes of defining the meaning of events and attribution contests in which individuals and groups struggle to define a situation and to manage and control it" in response to a devastating phenomenon (Eyerman 2015: 131). Jeffrey Alexander elaborates the four stages of this trauma process, in which stakeholders rely on symbolic devices to articulate trauma narratives. First, the nature of the pain and hurt must be identified; second, the victims must be named and identified; third, the relationship of the victims to wider members of society must be established; and fourth, responsibility and blame are attributed to perpetrators (Alexander 2004b: 12-15). Cultural trauma theory thus stresses the presence of abstract and supra-individual and cultural schemata that enable events to be "coded", "weighted", and "narrated" according to binary oppositions such as victims and perpetrators, heroes and villains, good and evil, purity and impurity, and sacred and profane (Alexander 2004a: 200-204). These symbolic representations enable wider audiences to recognise events that they have not experienced first-hand as being fundamental and indelible to their collective identity and collective memory. 
Various carrier groups are important for presenting competing interpretations of events to the public; this includes individuals and groups such as public intellectuals, victims, and civil advocacy groups, as well as institutions such as the state and media outlets. These struggles over meaning occur in multiple arenas and industries, ranging from news media, politics, law, academia, art, and entertainment. Nor are these struggles are not purely "symbolic", or concerned only with "interpretations": they encompass issues of responsibility (moral or legal), criminal justice, diplomacy, financial redress, and commercial interests. Once certain representations of trauma are routinized through repeated and regular commemorative processes - including commemorative ceremonies, monuments, museums, legislation, and education - cultural trauma develops into a structural force, even shaping the memories of geographically distant collectivities and future generations.

The cultural trauma approach overcomes a major shortcoming within existing literature on commemoration and collective memory, which has produced many instances of "successful" commemoration, but fewer instances of collective forgetting, repression, and amnesia (Conway 2010: 448). Crucially, cultural trauma theorists have sought to explain the absence of group-level trauma by asking whether or not carrier groups are able to "carry" the trauma to broader audiences. For instance, Rui Gao (2011), in a study of 20th Century China, attributes the scarcity of trauma discourse on Japanese atrocities in wartime China to political conditions under Mao: Rui demonstrates that the "trauma drama" of class struggle against the Kuomintang was a "ubiquitous and compelling force" which took priority over representations of the war against Japan (Gao 2011: 72). Bartmanski and Eyerman (2011) also reconstruct a case of trauma suppression surrounding the Katyn Massacre, as they demonstrate that the Soviets' slaughter of Polish soldiers and civilians became a distinctly Polish trauma only after the collapse of Soviet socialism, at which point carrier groups were able to narrate their traumatic experiences publicly and freely. These case studies demonstrate trauma construction is contingent on a number of material and symbolic constraints, including political censorship, economic capital, access to media outlets and cultural industries (including newspapers, book and magazine publishers, theatres, and film studios, to name a few), and wider socio-political contexts that facilitate or hinder the symbolic identification of victims and perpetrators with audiences.

If cultural trauma theorists agree on the role of narrative as the foundation of cultural trauma, there appears to be less consensus on whether or not "fictional" or "imagined" traumas have the potential to become cultural traumas. Whereas Alexander holds that "events that are deeply traumatizing may not actually have occurred at all" (Alexander 2004b: 8), Piotr Sztompka diverges from this view, suggesting that cultural traumas are located in real, "traumatogenic" events, which are instances of sudden, disruptive social change that affects large proportions of a population. These include violent events such as wars, foreign conquest as well as stock market crashes, and revolutions (Sztompka 2004: 158-160). It would be beyond the modest scope of this article to settle these seemingly contradictory positions on such a general point. Nonetheless, this case study shows a historic example in which the event was undoubtedly real and traumatogenic, yet trauma discourse did not arise: not due to active attempts by stakeholders to prevent the articulation of trauma narratives, but due to the scarcity of known "facts". This suggests that a minimal level of established facts is necessary to claim events to be traumatic: consequently, examples of purely fictitious or imagined cultural traumas are the exception than the norm. This study of the Matsumoto attack-which itself has rarely been the object of scholarly research in the English-speaking world - shows how social norms and conventions governing the discovery of facts can fail, and such a failure can thwart attempts to narrate trauma in terms of their moral impact on collective identity. The lack 
of reliable facts surrounding an event, such as the identity of the perpetrators, their modus operandi, and their motives, makes it difficult for actors to create convincing trauma narratives and make moral judgments about them (admitting, of course, that the immoral nature of events may be self-explanatory, such as in some terrorist attacks). Hence, this article calls attention to different social processes that discover and establish facts relating to an event, which then contribute to the subsequent attempts to attach moral meanings to them.

To do this, this article proposes a conceptual distinction between two sets of carrier groups of trauma, with reference to the division of labour involved in "trauma work" after a devastating event. First, "fact-finders" primarily aim to clarify and establish the factual circumstances of traumatic events. Second, "narrators" aim to communicate the moral significance of those events to broad audiences based on the known facts. Whereas previous literature on cultural trauma has tended to emphasise the role of narrators - public intellectuals in particular - as the primary carrier groups (Alexander 2004b; Baert 2015; Eyerman 2001; Eyerman 2011), this typology draws attention to a more diverse range of occupations and professions tasked with ascertaining the factual details of shocking, disruptive phenomena.

This distinction is partly indebted to the strong programme in cultural sociology (Alexander and Smith 2003), and its argument that facts are distinguishable from their "meanings": facts do not speak for themselves but need to be symbolically organised and narrated to have "meaning" with reference to "values" (Alexander 2003: 156). However, it is worth adding to this view that facts are not always self-evident and are frequently the outcome of socially mediated processes which "discover" them, especially in events of historical significance. As scholars of collective memory will likely agree, establishing what happened in the past (immediate or distant) is a deeply contentious and resource-intensive task, not only subject to professional disagreements among experts but also vulnerable to manipulation and revision by dominant groups. Collecting evidence to establish what happened in the aftermath of violence and destruction is therefore especially time-consuming, expensive, physically demanding, and emotionally draining. Following devastating events, it could take days and weeks, if not months, to approximate and calculate the loss and damage, even before narrators can take up the role of assigning the moral significance to them.

A number of professions are responsible for establishing the facts of a devastating event, even if they do not themselves directly or publicly communicate the meanings of those events. In the aftermath of wars and genocides, UN fact-finding missions, the military, peacekeeping forces, aid workers, and foreign correspondents help to estimate the damage and loss to local populations. In the aftermath of crimes and terrorist attacks, the police, intelligence services, coroners, and forensic scientists will likely play a leading role in clarifying the details of the case, to be put forward and contested in court at a later point. In other instances such as natural disasters, emergency services, the medical profession, and local volunteer groups (to name but a few) may help to establish the extent of destruction. For events that have happened in the past, the role of historians and archivists may become more important. Other professions may also help to quantify the losses financially: in many of these disruptive instances, insurance loss adjustors quantify the impact as economic loss, which can then form the legal basis for financial restitution. Put simply, these fact-finders provide a wealth of "data" - death and casualty tolls, official records, survivor and witness testimonies, audio-visual evidence, and forensic evidence - which narrators such as journalists, artists, and public intellectuals can then use to make claims about the moral significance of destructive and distressing events. The relationship between fact-finders and narrators is often mutually beneficial. Narrators such as news outlets rely on fact-finding professionals to provide clarity and lend authority to 
otherwise uncertain or chaotic situations, for example, to demonstrate that Hurricane Katrina was much more than an ordinary "storm" (Eyerman 2015: 41). In turn, experts benefit from greater media exposure and public authority by contributing to public debates.

A useful way to distinguish the two carrier groups is to understand their different relationships to the public. Fact-finders do not necessarily speak directly to the public: for aid workers in disaster zones, narrating trauma to the public is a secondary concern; for the police pursuing suspects, sharing sensitive information with the public may even be undesirable. By contrast, narrators fulfil their role as public communicators first, and investigators second. Of course, any ideal-typical distinction comes with exceptions, and there are instances when fact-finders can double as narrators, and vice versa. For example, police forces often publicly condemn terrorist attacks as heinous assaults on civic values. NGOs such as Human Rights Watch and Amnesty International can combine fact-finding and expertise with political advocacy in the hope of communicating the trauma of victimised groups to broader audiences. Journalists and documentary film makers can also be considered as carrier groups that move relatively fluidly between fact-finding and narrating. John Hersey's (1946) reportage of Hiroshima and Claude Lanzmann's (2007[1985]) epic documentary Shoah are primary examples in which discovering facts through witness testimony is inseparable from the act of communicating those testimonies to the public through artistic narration. Nonetheless, there are limits to the extent to which narrators can establish facts: journalists nor film makers have the occupational capacity to declare official death tolls, formally identify suspects, or quantify economic loss.

In cases when the facts of a disruptive event cannot be established, narrators struggle to attach moral meanings to them; consequently, even devastating events can fail to become traumas if known facts are in short supply. How could narrators convince audiences that fundamental moral values had been breached, if they cannot persuasively describe and explain what happened? Beyond the example discussed in this article, the disappearance of the Malaysian Airlines flight MH370 in March 2014 is another case in point. The sudden disappearance of a passenger aircraft carrying 227 passengers was itself a shocking event that reverberated across multiple countries, including Malaysia, China, and Australia. However, the ensuing - and still ongoing - difficulty in locating the aircraft's precise location and the lack of convincing explanations for its disappearance have meant that trauma narratives have been underdeveloped, leaving discursive space open for tenuous conspiracy theories (Lusher 2017). To date, narrators have struggled to convincingly demonstrate the nature of the plane's disappearance, extend symbolic identification with victims, or allocate responsibility. Thus, despite the presumed deaths of over 200 passengers and staff, and the anguish of families who have lost their loved ones, the event has yet emerged as a cultural trauma in any of the affected countries. When there are few known facts to back up their narratives, narrators cannot carry the trauma to more general audiences.

It should be clarified here that fact-finding is itself shaped through cultural factors. Factfinding is subject to "cultural constraints" in two senses of the term: first, socio-cultural norms and value systems that affect the whole of society, and second, professional norms and values that govern fact-finding activities within specific institutional settings. At the level of national or regional culture, norms constrain the reliability of data. Yang Jisheng's (2012) historiography of China's famine during the Great Leap Forward illustrates the difficulties of gathering reliable statistics for a period when rural starvation was a taboo topic for discussion and mortality rates were systematically distorted to downplay the extent of the famine. If political norms hampered Yang's attempts to gather accurate statistics, religious norms likely influenced 
Durkheim's (2002) statistics on suicide, as Jack Douglas (1967) argued. The moral bias against suicide in predominantly Catholic countries could have resulted in lower reported rates of suicide, either because victims' relatives sought to persuade coroners for the death to be classed as "accidents" (Douglas 1967: 205-207) or because the victim may have disguised the death as an accident (Ibid.: 208-209). This calls into question Durkheim's claim that Catholic countries enjoy lower suicide rates because of greater social solidarity.

At lower levels of generality, the production of facts as a form of knowledge is dependent on cultural norms governing professional institutions. As scholars of science and technology studies (STS) have argued, "normal science" is governed by norms and conventions which regulate what constitutes valid "scientific" "knowledge" and "discovery" (Bloor 1991[1976]; Latour and Woolgar 1986). In the laboratory, Latour and Woolgar argued, the production of facts depends on "a complex mixture of beliefs, habits, systematised knowledge, exemplary achievements, experimental practices, oral traditions, and craft skills" shared within professional fields (Latour and Woolgar 1986: 54). A scientific finding gradually becomes fact through a series of social processes within this professional culture - first outlined through repeated experiments, then elaborated and defended through working papers, conference presentations, and finally published as journal articles - until it eventually takes on a "quality which appears to place it beyond the scope of some kinds of sociological and historical explanation" (Ibid.: 107). These scientific standards contrast with other occupational cultures in the police, forensic science, and the judiciary, in which a combination of "direct evidence", such as fingerprints and DNA samples, and "witness statements" helps to ascertain the facts relating to a criminal case (Kruse 2016). In establishing identities of potential suspects, technologies such as CCTV (Douillet and Dumoulin 2015), fingerprint matching (Cole 2001), and DNA identification (Renard 2015, Robert and Dufresne 2015) rely on networks of specialist institutions such as analysis laboratories, investigative agencies, and databases, enabling specialists to identify matches with samples. Fact-finding is therefore a practice firmly grounded in social, cultural, political, technological, and historical contexts.

In incorporating some aspects of STS, especially the Actor-Network Theory (ANT), there is a potential tension between the separation of the "material" and symbolic worlds as advocated in cultural sociology and ANT's critique of such a division as being historically specific to "modern" Enlightenment thought, and therefore problematic (Latour 1993). ANT's conscious valuation of human and nonhuman agents as analytically equal units also raises questions about the potential agency of nonhuman "actants" (Latour 2005) - such as weapons used in war terrorism or natural phenomena such as hurricanes and earthquakes - in the creation of trauma narratives. A comprehensive application of ANT in the analysis of cultural trauma may indeed be possible, but it is not the aim of this article. Some of ANT's more radical proposals, such as the rejection of the division between nature and culture, scientific and political, or nonhuman and human, are of questionable utility in studying cultural trauma, for the obvious reason that cultural trauma is concerned with meanings human agents create about themselves and the world. Instead, I suggest a more modest fusion of STS with collective memory studies by opening up the black box of fact creation through a study of professional institutions, and how human uses and interactions with technologies may influence the social construction of collective trauma.

In what follows, this article reconstructs the aftermath of the Matsumoto Sarin Incident, in which fact-finders - including the police, forensic scientists, and journalists - failed to correctly identify the culprits and motives, because existing professional norms of police investigation and media reporting were ill-suited to deal with an unprecedented case of indiscriminate terrorism using sarin. The police's insistence on extracting a confession from an innocent survivor whom 
they suspected and news media's over-reliance on the police for information doubly hindered the identification of the attack's true culprits and an exploration of alternative scenarios. As new evidence was slow to emerge, this line of investigation stalled and the event risked becoming, like the MH370 disappearance, a "mystery". Consequently, until the 1995 Tokyo subway attack, stakeholders struggled to comprehend the event as an assault on fundamental cultural values despite the trauma and devastation experienced by an entire neighbourhood.

\section{The Context Leading Up to the Matsumoto Sarin Incident}

Aum Shinrikyō (commonly referred to simply as Aum) was a millenarian new religious movement founded by self-proclaimed guru Asahara Shōkō, which began in 1984 as a small yoga class called Aum Society (Oumu no Kai). ${ }^{1}$ Aum's belief system consisted of a syncretic, eclectic mixture of various religious traditions such as Hinduism, Tibetan Buddhism, New Age spiritualism, and later, Christianity. Urging his followers to renounce their worldly possessions (in essence, donating one's assets to the movement), Asahara poured scorn on consumer capitalism and promised spiritual enlightenment through a combination of ascetic practice and mystical experiences. Aum grew quickly in size, with younger generations comprising the vast majority of the membership in the context of a national boom in new religious movements, occultism, and spiritualism; in 1995, when the full membership was revealed, $75 \%$ of its members were in their twenties and thirties (Shimazono 1995: 384). In 1987, Asahara changed the name of the group to Aum Shinrikyō to better reflect his wish to turn the yoga class into a religion (Shinrikyō translates to "Religion of Truth"). With Asahara placing himself as the omniscient guru and prophet, Aum operated on a strict hierarchy based on the level of the individual's spiritual attainment: a system which, in reality, favoured those with academic and professional qualifications.

Although Aum started as a peaceful movement, Asahara's paranoid delusions, predilections for violence, and apocalyptic predictions soon came to define Aum's character. The 1990 general election, in which Asahara and twenty-four other candidates stood and suffered a humiliating defeat, was a turning point in the group's career. Disappointed by the public's lack of interest, Asahara changed the group's direction from salvation of the masses through conversion to takeover of the Japanese state by force (Tsukada 2011). ${ }^{2}$ Predicting that World War Three and a thermo-nuclear war were imminent and inevitable, Asahara claimed that Aum would become the new rulers of a post-apocalyptic world; to survive, however, they needed to militarize and defend themselves (Reader 2000). Asahara organised and ordered a small team of scientists to develop biological and chemical weapons to fight against Aum's imaginary enemy (the Judeo-Masonic conspiracy which controlled the Japanese government) and to prepare for impending doom (Tsuji 2011; Hirano 2011).

\footnotetext{
${ }^{1}$ In the English language, Reader (2000) and Shimazono (1995) provide arguably the most comprehensive histories of Aum Shinrikyō in the years leading up to the Tokyo sarin attack.

All Japanese names appear in Japanese style, with the surname first, unless otherwise stated.

${ }^{2}$ It is important to not exaggerate this turn as a sudden change from peaceful methods to relying on violence, not least because Asahara and his aides had already committed multiple murders before this election. In early 1989, Asahara ordered the murder of Taguchi Shūji, a dissident member, and in late 1989, he ordered the murders of anti-Aum lawyer Sakamoto Tsutsumi, his wife, and their one-year-old baby. Nonetheless, Asahara's former aides have stated that the election loss led to his distrust of the Japanese public, which may have subsequently contributed to Aum's turn to terrorism (Jōyū 2012; Noda 2009).
} 
Two concepts in Aum's belief system were particularly important in justifying its turn to militarism and violence: Vajrayāna and poa. In Aum's interpretation, Vajrayāna ("diamond vehicle") designated a mode of salvation which justified the enlightened guru to do whatever is necessary for the greatest good. This stood in contrast to lower "vehicles" to enlightenment, Hinayāna ("small vehicle") and Mahayāna ("large vehicle") which stressed individual enlightenment and conversion of the masses respectively. The Vajrayāna principle that the guru's orders were sacred and inviolable justified violence against members and outsiders through poa, a ritual of "transference of souls" (Shimada 2012 vol.1: 164-171). According to the principle of poa, Asahara, as an omniscient guru, could kill individuals whom he knew to commit evil deeds before they actually committed those acts: this prevented the victim from accruing negative karma and promised them a better rebirth. As an enlightened figure, the guru (and by extension his followers who carried out the orders) would not accrue negative karma from killing either (Reader 2000; Shimazono 1995: 406). Following the election defeat, Asahara signalled that the Japanese population was no longer able to be saved by conversion, and that they had to be "saved" in death through poa (Tsukada 2011: 324-325; Noda 2010: 31; Hayakawa and Kawamura 2005: 166).

Known as "secret work", militarization was carried out by Asahara's closest aides, hidden from rank-and-file believers. Aum's scientists - many of whom had advanced degrees in the natural sciences but were by no means experts - struggled to produce any biological weapons. However, they eventually found more success in chemical weapons, managing to produce lethal quantities of phosgene, sarin, and VX. Following failed assassination attempts on Aum's perceived enemies using sarin (including Ikeda Daisaku, the leader of the new religious movement Sōka Gakkai International, and Takimoto Tarō, a vocal critic of Aum), Asahara ordered a "field test" on the city of Matsumoto in central Japan. The human experiment had a practical aim of sabotaging a trial in which Aum was a defendant. Aum had purchased land with the intention of building a commune, but without telling the previous landowner of this fact. Amidst local protests, the former landowner had sued Aum to nullify the transaction on the basis that Aum provided misinformation; the verdict was expected to be in the landowner's favour (Reader 2000: 209; Shimada 2012 vol.1: 26). With the verdict to be delivered on 28th June, Asahara ordered Murai Hideo, the head scientist at the helm of the militarization programme, to attack a residential complex for members of the judiciary to kill or maim them. ${ }^{3}$ On the night of 27 th June at around $10.30 \mathrm{pm}$, Aum's customised truck drove through Matsumoto as it sprayed sarin. A gentle breeze carried the vapours throughout the neighbourhood, entering homes within minutes. Seven were killed in the attack, and an eighth victim died in 2008 from physical aftereffects of sarin poisoning. Scores were hospitalised overnight and hundreds more injured, as local authorities struggled to comprehend what had happened in the quiet neighbourhood. Aum accomplished the two goals of testing a chemical weapon on a large population and delaying the outcome of the trial.

\section{The Fact-Finders Fail: the Immediate Aftermath}

The nation woke up to the news of the incident with shock and confusion. Matsumoto, a small regional city in the centre of Honshū Island with a population of around 200,000, was hardly an obvious target for terrorism. Historically, a number of domestic terrorists - many of them militant

\footnotetext{
${ }^{3}$ Yomiuri Shimbun (1995) "Matsumoto sarin jiken saisho no hyōteki wa Nagano chisai shibu", 13th July (Evening Edition—henceforth Eve. Ed.), p.19.
} 
Marxist guerrillas - had targeted public institutions such as banks and police stations using firearms and explosives. The details of what happened at Matsumoto therefore did not fit with known modus operandi of existing right-wing or left-wing armed groups. Moreover, by the 1990s, a bloody history of sectarian violence among militant leftist groups had led to their decline (Igarashi 2007). For security authorities, the attack was wholly unexpected and unprecedented.

The primary fact-finders in the immediate aftermath of the attack were emergency service responders, the medical profession in Nagano Prefecture, and investigators from the Nagano Prefectural Police. As initial news reports show, evidence was sparse. On the day after the attack, reporters only knew that many had died suddenly and that scores of people had been hospitalised due to a nauseous gas. The "crime scenes" were multiple and dispersed over a large area; Aum had sprayed sarin from a moving vehicle, leaving very few pieces of physical evidence in their path. The emergency services did not even know what the gas was, let alone how it had been spread. ${ }^{4}$ This uncertainty, however, did not stop the police or the media from making accusations based on flimsy circumstantial evidence. The police's most urgent line of enquiry was to investigate Kōno Yoshiyuki, an office worker and father who was the first to contact emergency services; his house was next to the car park where Aum had begun to spray sarin. On the night of the attack, he noticed a strange sound outside and found his dogs convulsing on the ground. As he came back into the house to alert his wife, he found her collapsed on the floor; as he called for an ambulance, he himself was also poisoned by the gas (Kōno 2001). His wife fell into a coma from which she never awoke until her eventual death in 2008, while Kōno and his eldest daughter were also hospitalised.

Both the police and the national press - the former as fact-finders and the latter as a combination of fact-finders and narrators - were misled by their professional norms and expectations. In the initial days after the attack, it did not occur to anyone in the immediate aftermath that the incident could be a malicious, indiscriminate attack on civilians. Instead, the police and media inferred the event was a chemical experiment gone wrong. In this improvised scenario, Kōno was trying to make a potent pesticide by mixing chemicals and called for help when it produced a toxic gas. On 30th June, national newspaper Asahi Shimbun reported the Prefectural Police had concluded that "an unspecified mistake while combining chemicals produced a toxic gas". 5 Following this line of investigation, the media collated circumstantial evidence and eye-witness accounts that supported this hypothesis. Unsubstantiated reports claimed Kōno had admitted responsibility to his son and warned him to prepare for police investigation (Kōno 2001: 88). These implicit admissions of guilt were entirely fictional; it is possible that the police had informally fed the information to the media, so that public reports of his culpability would pressure Kōno to confess (Ibid.: 242). Circumstantial evidence seemed to point towards his involvement: there were sightings of a mist around Kōno's house, four hours before the initial emergency calls ${ }^{6}$; animals in his garden, including his dogs and fish in the pond, had died; the plants in his garden had withered. One early report concluded that it was "a situation in which it was impossible not to suppose that some kind of chemical had been spilled". ${ }^{7}$ Police located buckets and dishes in the

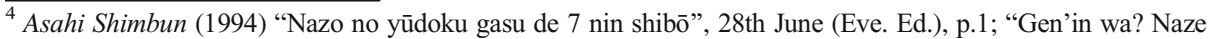
Jūtakuchi?", 28th June (Eve. Ed.), p.14; "Nemuri no machi o doku ga osotta”, 28th June (Eve. Ed.), p.15; Yomiuri Shimbun (1994) "Nagano Matsumoto no chūshinbu jūtakugai de yūdoku gasu, 7 nin shinu”, 28th June (Eve. Ed.), p.1.

${ }_{5}^{5}$ Asahi Shimbun (1994) "Matsumoto yūdoku gasu, chōgō misu de hassei”, 30th June (Eve. Ed.), p.19.

${ }^{6}$ Yomiuri Shimbun (1994) "Matsumoto no yūdoku jiken shiroi kiri, 4 jikan mae kara”, 1st July, p.35.

7 Yomiuri Shimbun (1994) “Matsumoto gasu jikojūtakugai no niwa de yakubutsu jikken!?”, 29th June, p.31. Translations by the author.
} 
garden, supposedly used for mixing chemicals. Initial forensic analysis indicated the presence of phosphates, a compound commonly found in pesticides. Meanwhile, Kōno strongly denied any involvement when the police interviewed him in hospital. He was effectively placed under police supervision as he recuperated. ${ }^{8}$

In the first few days after the attack, the "Matsumoto Toxic Gas Incident", as it was reported in the media, did not develop into national trauma discourse. Despite the tragedy of an entire community torn apart by the attack, there was no sense that fundamental moral values had been breached, or that Japan's civil values had been threatened. Matsumoto's relative marginality as a small regional city also arguably added to public perceptions of the event as a relatively distant phenomenon. Furthermore, although the attack caused panic overnight, there was no breakdown of social order. In all other parts of the country, life went on as normal, and there was little sense of systemic breakdown or crisis, as was the case in the Tokyo sarin attack nine months later.

The initial lessons the media drew from the incident demonstrate how widely off the mark factfinders were. ${ }^{9}$ The Asahi wrote in the editorial on 29th June, "[w]hy did he try to make a pesticide by himself, what kind of pesticide did he try to make, why did it result in so many casualties; there are many unclear points, but it is a horrific event that should not have happened". The editorial pontificated that "this incident reiterates the fact that our lives are side-by-side with harmful chemicals"; it concluded, "[t]here are, in fact, many dangerous substances around us that, once we make a mistake of mishandling, could lead to irredeemable outcomes. This incident teaches us the eeriness of this fact". ${ }^{10}$ Although some scientists cast doubt on this "accidental narrative" given the scientific impossibility of creating so potent a gas from pesticides and other chemicals found in Kōno's shed, ${ }^{11}$ both the police and media set up this narrative based on heavy speculation and scant evidence.

This accidental narrative suddenly collapsed on 4th July, a week after the attack, when forensic scientists formally identified the toxic gas as sarin. ${ }^{12}$ The history of sarin as a chemical weapon developed by the Nazis, which "even Hitler hesitated to use" due to its high toxicity, introduced a new, sinister dimension to the incident. ${ }^{13}$ The discovery should have exonerated Kōno at this point. After all, he lacked the required expertise, ingredients, or apparatus to produce the deadly nerve agent (Aum, by contrast, had custom-built a laboratory for this purpose). Moreover, he had no motive nor the resources to be able to commit the attack by himself single-handedly. Instead of abandoning this line of enquiry, however, the police and media together modified the accidental narrative to imply Kōno had produced the gas deliberately. This was partially due to the police's ignorance of sarin production methods (NHK Supesharu Shuzai Han 2013: 122): in the media, some self-styled "experts" suggested sarin could be made by mixing chemicals in a bucket (Kōno 2001: 138). It is apparent that the idea that Kōno could be innocent never crossed the minds of investigators or reporters at this point. $^{14}$

\footnotetext{
${ }^{8}$ Asahi Shimbun (1994) "Matsumoto yūdoku gasu, chōgō misu de hassei”, 30th June (Eve. Ed.), p.19.

9 Asahi Shimbun (1994) "Shirōto no chōgō ni ayausa san konnyū de gasu", 29th June (Eve. Ed.), p.19; Yomiuri Shimbun 1st July 1994, p.3.

${ }^{10}$ Asahi Shimbun (1994) "Yakubutsu to tonariau kurashi no kowasa", 29th June, p.5. All translations of Japanese texts by the author.

${ }^{11}$ Asahi Shimbun (1994) "Shinkei gasu ni ruiji ka", 1st July (Osaka Edition), p.31.

${ }^{12}$ Asahi Shimbun (1994) "Shinkei gasu 'sarin' kenshutsu", 4th July, p.1; Yomiuri Shimbun (1994), "Matsumoto no shūdan higai Nachi kaihatsu no dokugasu 'sarin'”, 4th July, p.31.

${ }_{13}$ Yomiuri Shimbun (1994) "Sarin kakuheiki nami sasshōryoku”, 8th July, p.15.

${ }^{14}$ Asahi Shimbun (1994) "Shinkei gasu 'sarin' kenshutsu", 4th July, p.1; "Sarin seisei no kanōsei bunseki", 4th July, p.15; Yomiuri Shimbun (1994) “Matsumoto no chūdoku jiken shinkei gasu 'sarin’ kenshutsu”, 4th July, p.1.
} 
The emergent frame of the attack as a deliberate act of mass murder created a sense of collective unease, raising the possibility of narrators situating the attack as a heinous attack on innocent civilians. However, the trajectory of discourse surrounding the Matsumoto attack did not develop in this direction, for multiple reasons. Firstly, the misidentification of the culprit as a lone killer meant that the attack was construed as the result of a local dispute, not as a politically motivated attack. To this effect, the media defamed Kōno to situate him as the culprit; this included an unsubstantiated rumour that a man (hinted to be Kōno) had boasted about a weapon that could kill dozens (Ibid.: 139; 171-174). ${ }^{15}$

Secondly, the attack diverged from patterns of domestic organised violence, in which Marxist guerrillas often used firearms and explosives. They tended to target public institutions, such as government buildings, public transport, and banks, not residential streets of a regional city. When terrorist groups attacked civilians in hostage situations (such as when leftist guerrillas hijacked an airplane and flew to North Korea in 1970), the culprits had claimed responsibility and made their political demands clear. When the "usual suspects" failed to claim responsibility for the attack, there were no clear suspects besides Kōno. This likely motivated the police to continue to treat Kōno as the prime suspect. Thirdly, few other pieces of evidence emerged, prompting the police to obstinately rely on the tried and tested method of extracting a confession from the suspect.

Despite an expert analysis that Kōno could not have produced sarin with the ingredients and apparatus at his house, ${ }^{16}$ the police continued to press Kōno for information as a key person of interest. When Kōno was discharged from hospital on 30th July, he held a press conference to protest the vilification of his character and agreed to police interviews. ${ }^{17}$ Konno sat two days of intensive questioning, at which point his health deteriorated again. He also refused further interviews as he took offence at the police's attempt to coerce him to confess (Ibid.). Gradually, Kōno also began to actively challenge predominant representations of him as a suspect by meeting with reporters and experts: experts concluded that it was impossible for Kōno to have made sarin (Ibid.: 117-122). This led to a gradual shift in symbolic representations of Kōno from a mysterious misanthropic figure to a devoted husband and father who suffered a tragedy. Although he was not fully exonerated, the plurality of media representation of Kōno, together with the absence of evidence, meant that the narrative of Kōno as the culprit gradually lost persuasiveness. It is worth noting that media outlets do not appear to have seriously explored alternative scenarios that exonerated Kōno. Until Kōno personally intervened through media appearances, news gathering seems to have been almost solely dependent on the police for any information — another failure of professional norms.

Fact-finders struggled to make progress. The Nagano Prefectural Police had gained evidence that Aum's proxies had purchased massive quantities of sarin ingredients. There were also reports of strange smells near Aum's headquarters in July 1994. In September, the police secretly obtained soil samples containing sarin residue near Aum's facilities (NHK Supesharu Shuzaihan 2013: 128-129). However, these findings were kept secret and did not lead to overt police operations against Aum; there was still insufficient evidence to investigate Aum for Matsumoto, and a legal

\footnotetext{
${ }^{15}$ Asahi Shimbun (1994) "Sarin izen nazo, nazo", 19th August, p.3.

${ }^{16}$ Asahi Shimbun (1994) "Ōshū shita yakuhin 24 shurui de sarin no gōsei fukanō", 11th July, p.19; Yomiuri Shimbun (1994) "Shūdan gasu chūdoku jiken fusso kagōbutsu, hakken sarezu”, 6th July, p.14.

${ }^{17}$ Asahi Shimbun (1994) “Sarin no namae, hajimete shitta' Matsumoto gasu chūdoku daiippō tsūhōsha kaiken”, 30th July (Eve. Ed.), p.21; “Aratamete kanyo o hitei Tsuhō shita kaishain ga taiinshi kaiken”, 30th July (Eve. Ed), p.21; Yomiuri Shimbun (1994) "Matsumoto no dokugasu yūdoku jiken kaishain taiin”, 30th July (Eve. Ed.), p.11.4.
} 
loophole meant sarin production was not itself a criminal offence. The Nagano Prefectural Police therefore remained on standby, unable to launch a large-scale operation. As new information failed to publicly emerge, narrators struggled to produce any convincing trauma narratives; media outlets slowly fell silent and eventually stopped reporting on Matsumoto but stopped short of vindicating Kōno or offering apologies. Victims and bereaved families also expressed sorrow and suffering on individual terms, but not in relation to cultural identity and values. ${ }^{18}$

For the rest of 1994, then, the Matsumoto Sarin Incident became a mystery, and an "enigma", but certainly not a trauma pertained to collective identity or memory. ${ }^{19}$ Though an "eerie" ("bukimi") and "frustrating" ("modokashii") case, the incident did not shake the foundations of collective identity as the Tokyo attack would the nextyear. ${ }^{20}$ In 1994, not once was the Matsumoto sarin attack identified as a "terrorist attack" by national newspapers Asahi Shimbun or Yomiuri Shimbun. One example demonstrates the relatively small impact that the Matsumoto attack made on the public consciousness. In the 1994 end of the year readers' poll in the Yomiuri (see Table 1), the Matsumoto Sarin Incident was voted to be the tenth most important event in 1994, behind the summer heatwave and drought (no.1), a popular baseball team winning the championship (no. 4), and the price hike of rice caused by a historic drought (no. 8). ${ }^{21}$ This stands in contrast to the Tokyo Subway Sarin Incident and the Aum Affair, which, in the same poll a year later, was voted as the second most important news event after the Great Hanshin (Kōbe) Earthquake. ${ }^{22}$ In short, in 1994 , the Matsumoto sarin attack was hardly recognised as a national trauma, and risked falling into obscurity as an unsolved mystery. Meanwhile, Aum continued to attempt "poa" of various enemies using chemical weapons throughout 1994.

\section{5 and the Tokyo Sarin Incident as a Turning Point}

The transformative moment came on New Year's Day 1995, as Yomiuri Shimbun's exclusive report relayed earlier police discoveries that traces of sarin residue had been detected in Kamikuishiki village, Yamanashi Prefecture. Although the article itself did not mention Aum by name, Kamikuishiki was known as Aum's headquarters. ${ }^{23}$ Other news outlets followed suit, sometimes mentioning Aum by name, to which Aum responded by vehemently denying involvement and suing media outlets for defamation. ${ }^{24}$ As Aum came under greater public scrutiny, journalists unearthed a litany of past troubles and conflicts, contributing to their notoriety. In the author's interview with Kōno in April 2015, he recalled that it was around this time that the media began to realise that he was innocent and that Aum was behind the Matsumoto attack - but the facts were not yet strong enough to warrant public apologies (Kōno 2015). Another turning point came in late February, when Aum members kidnapped Kariya Kiyoshi, a Tokyo-based public notary who had been in a dispute with

\footnotetext{
${ }^{18}$ Yomiuri Shimbun (1994) "Matsumoto no ‘sarin jiken' kara 2 kagetsu”, 22nd August, p.30.

${ }^{19}$ Asahi Shimbun (1994) "Sarin jiken no modokashisa”, 3rd December, p.4; Yomiuri Shimbun (1994) "Matsumoto sarin jiken kara 3 kagetsu", 27th September, p.13.

${ }^{20}$ Asahi Shimbun (1994) "Sarin jiken no modokashisa", 3rd December, p.4; "Nippon, tadaima gogo 3ji" 30th December, p.5; Yomiuri Shimbun (1994) "Kyōsei no nakami ga towareta 94 sesou", 29th December, p.3.

${ }^{21}$ Yomiuri Shimbun (1994) "1i wa kirokuteki mōsho dokusha ga eranda 94 nen Nihon 10 dai nyūsu", 25th December, p.14.

22 Yomiuri Shimbun (1995) "95 dokusha ga erabu kokunai 10 dai nyūsu", 24th December, p.14.

${ }^{23}$ Yomiuri Shimbun (1995) "Yamanashi no sanroku de sarin zanryūbutsu o kenshutsu", 1st January, p.1.

${ }^{24}$ Asahi Shimbun (1995) "TBS to Fusōsha o 'Meiyo Kison' to teiso", 7th January, p.30; “Oumu Shinrikyō ga Asahi Shimbunsha nado o teiso 'Shūkan Asahi de Meiyo Kison'”, 10th January, p.26; Yomiuri Shimbun (1995)

"Oumu Shinrikyō ga Shinchōsha nado uttae", 14th January, p.30.
} 
Aum over his sister's membership. Kariya later died after being forcibly administered a powerful barbiturate. As Kariya had warned his friends that if anything happened to him, Aum would be likely responsible, his disappearance added to public calls for Aum to be investigated. ${ }^{25}$ As Asahara discovered that a national police raid of Aum's premises was imminent, Aum hastily concocted a plan to attack the Tokyo subway to sabotage the police investigation.

At around 8 am on 20th March, five men each boarded a train on different lines carrying bags of sarin solution wrapped in newspaper, puncturing them with sharpened umbrellas as they disembarked and fled. The vaporised sarin gas quickly spread through the carriages, and at one station, passengers kicked the bags onto the platform in a panic, exacerbating the situation. The attack killed a total of thirteen and injured over 6000 commuters. Unlike Matsumoto, the political message of the Tokyo attack was obvious: the three subway lines the culprits targeted (Hibiya, Marunouchi, and Chiyoda) all passed through the bureaucratic nerve centre of Kasumigaseki-an area which houses various ministries, the Tokyo District Court, High Court, and the Supreme Court — as well as past the business district of Ōtemachi and popular retail districts of Shinjuku and Ginza.

Even as the nation struggled to make sense of the scale and intent of the attack, the media immediately condemned the attack as "an unforgivable challenge to society". ${ }^{26}$ Even before the media had identified the perpetrators, they adopted a framework of moral dualism, suggesting that the attack was committed by a "dark, twisted shadow lurking somewhere in this peaceful and prosperous society". ${ }^{27}$ Strongly hinting at Aum's involvement, the media suggested that "multiple fanatics" were likely behind the attack. ${ }^{28}$ Even if Aum was not explicitly named, journalists framed articles on the attack alongside articles and timelines discussing Aum's alleged involvement in sarin manufacture. ${ }^{29}$ A sense of "eeriness" (bukimi) permeated the national mood. ${ }^{30}$ Prime Minister Murayama Tomiichi decried the attack as "unforgivable" and vowed to bring the perpetrators to justice. " "It is no exaggeration to say that the subway sarin incident is horrific violence against all humans - no, against all life", wrote the weekly contemporary affairs magazine Sunday Mainichi. ${ }^{32}$ In some ways, the Matsumoto sarin attack was catalytic to the instantaneous comprehension of the Tokyo attack as a cultural trauma. As a recent example of a sarin attack, Matsumoto provided a reference point for the public to vividly recall the horrors of the chemical weapon: the "nightmare" of Matsumoto had returned to haunt Japan once again. ${ }^{33}$ The police therefore categorised the Tokyo attack as an "organised indiscriminate terrorist incident" straightaway. ${ }^{34}$ Put simply, the Tokyo attack immediately became a cultural trauma (Ushiyama and Baert 2016).

Regrettably, subsequent social ramifications of the Aum Affair in Japanese society are beyond the scope of this article and are better discussed elsewhere (see, e.g., Baffelli and Reader 2012; Gardner 1999; Hardacre 2007; Kisala and Mullins 2001; Pendleton 2009). In relation to the Matsumoto case,

\footnotetext{
${ }^{25}$ Asahi Shimbun (1995) "Nanika attara keisatsu ni” no memo", 9th March, p.35; Yomiuri Shimbun (1995) "Shinagawa no kōdhō yakuba jimuchō rachi", 4th March (Eve. Ed.), p.11.

${ }^{26}$ Asahi Shimbun (1995) "Dokugasu tero no sokoshirenu kyōfu (Shasetsu)", 21st March, p.5.

27 Yomiuri Shimbun (1995) "Yurushigatai chikatetsu sarin jiken", 21st March, p.1.

${ }^{28}$ Yomiuri Shimbun (1995) "(Shasetsu) Kyōshinteki na hankō o danjite yurusuna”, 21st March, p.3.

${ }^{29}$ Yomiuri Shimbun (1995) "Chikatetsu dokugasu taisakushitsu o setchi”, 20th March (Eve. Ed.), p.3.

${ }^{30}$ Asahi Shimbun (1995) "Tōkyō no chikatetsu sarin jiken", 21 March, p.1; "Oumu kyōdan no giwaku ni semare (Shasetsu)", 23rd March, p.5.

${ }^{31}$ Asahi Shimbun (1995) "Shūkan hōkoku", 27th March, p.5; Yomiuri Shimbun (1995) "Jūsōbi, bōdoku masuku de totsunyū. 'Oumu Shinrikyō' sousaku 3.22 dokyumento”. 22nd March (Eve. Ed.), p.2.

32 Sunday Mainichi (1995) "Sarin no senritsu: Gajōni fumikonda sōsa no kakushin", 9th April, V74(19), p.20.

${ }^{33}$ Asahi Shimbun (1995) "Me ga mienu, iki dekinu... Musabetsu no kyōfu mata", 20th March (Eve. Ed.), p.15; Yomiuri Shimbun (1995) “Tonai Chikatetsu de hassei shita mōdoku gasu jiken”, 20th March (Eve. Ed.), p.1.

${ }^{34}$ Yomiuri Shimbun (1995) "Tonai Chikatetsu ni mōdoku gasu, sarin zanryūbutsu? Kenshutsu. Shibō 6, Fushō 900 nin” 20th March (Eve. Ed.), p.1.
} 
Table 1 “Top Ten News of 1994, as selected by readers" (Yomiuri Shimbun, 25th December 1994; pg. 14)

1. Record heat wave leads to serious water shortages.

2. Astronaut Mukai Chiaki goes to space.

3. Ōe Kenzaburō wins the Nobel Prize for Literature.

4. Baseball team Yomiuri Giants win the championship.

5. Airbus airplane crash lands at Nagoya airport, killing 264.

6. Political instability after three successive Prime Ministers take office in one year.

7. Bullying in schools leads to a series of suicides.

8. Rice shortage results in price hikes.

9. Sumo wrestler Takanohana is promoted to the rank of Yokozuna (the highest title).

10. Seven die as a result of toxic gas "sarin" (Matsumoto).

the discovery of its true culprits was a mixed blessing for fact-finders. As the police raided Aum's premises two days after the attack (contrary to Asahara's initial aims to divert attention from them), investigators found massive quantities of sarin ingredients, confirming Aum's culpability. As the investigation progressed, it became increasingly clear that Kōno had been falsely accused of the earlier attack in Matsumoto. Alongside a torrent of media coverage on the Tokyo sarin attack, a flurry of "sincere apologies" appeared in newspapers, magazines, and on television, apologising for giving the impression that Kōno was the culprit. The Nagano Prefectural Police also issued a public statement of "regret" surrounding the investigation in June that year. ${ }^{35}$ As Aum's senior disciples were arrested from April onwards (culminating in Asahara's arrest on 16th May), they also admitted their involvement in the Matsumoto attack; the culprits were rearrested in July, several weeks after the first anniversary of the attack. At this point, the media could now confidently include Matsumoto as an instance within the cultural trauma of the Aum Affair(“Oumu Jiken"). In this new, rearticulated trauma narrative, Matsumoto represented a key turning point as Aum's first foray into terrorism. However, because of the delayed articulation of trauma narratives, and the much bigger scale of the Tokyo sarin attack, Matsumoto never became a cultural trauma independent of the greater subsuming label of the Aum Affair. Moreover, public institutions now faced an embarrassing and inconvenient question of how to acknowledge Matsumoto as a shameful case of false accusation.

\section{Commemorating Matsumoto as a Difficult Past}

The first anniversary of the Matsumoto attack coincided roughly with confessions by its true perpetrators. In line with much of media coverage on the Aum Affair at the time, commemorative reports urged that the entirety of Aum's violence must be uncovered and Aum held accountable with the full force of the law. Commemoration of Matsumoto as an attack on innocent civilians, however, had to be juxtaposed with the media's recognition of their grave errors the previous year. This prompted newspapers to repeatedly make apologies, and to run special reports examining their coverage of Matsumoto the previous year. ${ }^{36}$ Newspapers expressed regret for relying on police information excessively without independent fact-checking, and for ignoring experts' suggestions that Kōno could not have made a potent nerve gas. ${ }^{37}$ Apologies were not restricted to print media: mainstream TV

\footnotetext{
35 Yomiuri Shimbun (1995) "Matsumoto sarin jiken Nagano Kenkei ga Kōno san taku otozure 'ikan no i'”, 12 th June (Eve. Ed.) p.19.

${ }^{36}$ Asahi Shimbun (1995) "Matsumoto sarin jiken kara 1 nen: izoku no omoi”, 25th June, p.33; Yomiuri Shimbun (1995) "Matsumoto sarin 7 nin no giseisha", 26th June, p.26.

${ }^{37}$ Asahi Shimbun (1995) "Kōno san ni owabi suru”, 14th June, p.5; "Matsumoto sarin jiken”, 8th July, p.37; Yomiuri Shimbun (1995) “Kenshō 'Matsumoto sarin’ hōdō”, 7th July, p.19.
} 
broadcasters also aired special segments examining how their news coverage had led to an uncritical accusation of Kōno. Perhaps unsurprisingly, these expressions of apology and regret did not come from sincerity alone. Earlier in the year, Kōno had sought help from the Japan Federation of Bar Associations for violation of human rights and had initiated legal action against major media outlets. During this process, he had agreed to drop the lawsuits if the media outlets individually issued public apologies (Kōno 2001: 214-227).

Commemorative media coverage of Matsumoto reversed Kōno's image from suspect to victimhero. In the new retelling of the trauma drama, the media recast Kōno as a victim-hero protagonist who persevered through formidable adversity. He was victimised three times over by the attack: he was personally injured, his wife fell into a coma from which she never regained consciousness until her passing in 2008 , and his reputation was severely damaged by the allegations. Though Kōno never spoke as an official representative for Matsumoto victims, his public interventions had now gained moral authority beyond any other individual affected by the attack. Kōno decried the investigative process and the police's forceful attempts to extract a confession, as well as the speculative and irresponsible media coverage. ${ }^{38}$

The commemoration of Matsumoto has stood apart from other crimes committed by Aum, as the false accusation has been a recurring theme in remembering Matsumoto alongside condemning Aum's violence. Thus, unlike the commemoration of the Tokyo attack, which has been characterised by unequivocal moral condemnation of Aum as a mind-controlling cult (Baffelli and Reader 2012; Ushiyama and Baert 2016), the symbolic opposition of Japan as good and Aum as evil has been attenuated somewhat in public discussions of Matsumoto as the media have had to acknowledge their own moral transgressions. For example, in 1999, Yomiuri Shimbun and Asahi Shimbun both ran a series of reports marking five years since the Matsumoto attack. The reports featured interviews with survivors still suffering from physical and psychological aftereffects of sarin poisoning ${ }^{39}$ and stories of loss from victims' families, ${ }^{40}$ but also included extended interviews with Kōno in which he called for more financial support to sarin victims. ${ }^{41}$ Asahi Shimbun's tenth anniversary commemorative coverage also focused on the failings of media institutions, devoting considerably less space to the context of the attack or experiences of victims besides Kōno and his family. ${ }^{42}$ The centrality of Kōno as the protagonist of Matsumoto as a tragic drama was repeatedly emphasised as the Matsumoto Mayor made annual visits to Kōno's unconscious wife in hospital. Newspapers reported on the Matsumoto Mayor's annual visitations to Kōno and his wife, even when other forms of commemorative media coverage were absent. ${ }^{43}$

\footnotetext{
${ }^{38}$ Asahi Shimbun (1995) "Matsumoto sarin jiken", 8th July, p.37; "Matsumoto sarin jiken no daiichi tsūhōsha, Kōno Yoshiyuki san no owaranu takakai", 17th July, p.35; Yomiuri Shimbun (1995) "Matsumoto jiken de Oumu no Asahara hikoku ra taiho", 17th July, p.31.

39 Asahi Shimbun (1999) "Sarin no kyōfu kiezu: Matsumoto sarin jiken, kyō de 5 nen", 27th June, p.25; Yomiuri Shimbun (1999) "Kyōkō no ato: Matsumoto sarin jiken kara 5 nen (1)", 22nd June, p.28.

${ }^{40}$ Yomiuri Shimbun (1999) "Kyōkō no ato: Matsumoto sarin jiken kara 5 nen (3)”, 24th June, p.34.

${ }^{41}$ Asahi Shimbun (1999) “"Higaisha shien no jūjitsu o' Matsumoto sarin jiken 5 nen de sinpo", 28th June (Nagano Ed.), p.27; (2004) “"Mimai uketekureta. Omoi’ Kōno san tsuma no nyūin saki ni Oumu”, 27th June (Nagano Ed.), p.32; Yomiuri Shimbun (1999) "Kyōkō no ato: Matsumoto sarin jiken kara 5 nen (2)", 23rd June, p.26.

${ }^{42}$ Asahi Shimbun (2004) "Datsu 'Hannin shi hōdō' o mosaku", 23rd June, p.37; "Kōno Yoshiyuki san ga furikaeru", 24th June (Nagano Ed.), p.27; "Matsumoto Misuzugaokakō moto hōsō buin”, 26th June (Nagano Ed.), p.27; (2005) "Hassei 11 nen, kaifuku inoru Kōno san tsuma o shichō ga mimai", 27th June (Nagano Ed.), p.29.

${ }^{43}$ Asahi Shimbun (2004) “"Teisei wa sumiyaka ni’ Kōno Yoshiyuki san, shinpo de teigen”, 27th June (Nagano Ed.), p.37; Yomiuri Shimbun (2000) "Matsumoto sarin jiken kara, maru 6 nen", 28th June, p.32; (2002) "Matsumoto sarin jiken no Kōno Sumiko san Ariga Shichō ga mimai”, 28th June (Nagano Ed.), p.32.
} 
Kōno has been the subject of commemoration in television and film as well. The 2000 feature film Japan's Black Summer: False Accusation (Nihon no kuroi natsu: Enzai) by director Kumai Kei reconstructs the night of the Matsumoto attack and the subsequent police investigation (Kumai 2000). In the film, a team of high-school reporters interviews a local television station and a character based on Kōno to retrace the circumstances of the attack, to discover why an innocent victim was suspected as the perpetrator. The film was made with Kōno's assistance, and some scenes were filmed inside his home. Similarly, a 2009 TV documentary-drama by broadcaster Fuji Terebi recreated Kōno and his family's ordeal, featuring interviews with Kōno and his children. ${ }^{44}$ In these symbolic representations, the primary narrative centred on Kōno's personal biography, not on the broader context of Aum's crimes.

The focus on Kōno as a subject of commemorative media coverage arguably had other implications, namely, the isolation of institutional failures to this one instance as an exceptional "one-off" to the effect of neglecting discussions about other equally serious failures by the media and the state in relation to the Aum Affair. Three examples deserve attention. The first is the so-called TBS scandal. In 1989, the TV broadcaster TBS was visited by high-ranking Aum disciples. TBS executives were pressured into secretly showing them unaired interview footage with a lawyer named Sakamoto Tsutsumi, who represented parents of Aum believers opposed to their children joining the movement. After the disciples relayed the interview contents (which were highly critical of Aum) back to Asahara, Asahara ordered Sakamoto and his family to be killed. When details of this meeting emerged over the course of investigation in 1995, TBS instigated a cover-up until it was forced to admit in 1996 that the encounter took place, leading to the CEO's resignation (Hardacre 2007). Second, various media outlets had invited Asahara to appear on TV debates and variety shows in the early 1990s, while downplaying controversies Aum was already embroiled in, including the "disappearance" of the Sakamoto family (a case which remained unsolved until 1995). Media outlets therefore failed to exercise due diligence in researching the controversial background of the movement in the early 1990s, while contributing to Aum's PR strategy. Third, the intense national reaction against Aum following the subway attack resulted in civil rights violations by state authorities against Aum believers, including false arrests of Aum members, the rejection of resident records submitted by believers, and barring children of Aum members (including Asahara's children) from receiving compulsory education. Unlike Matsumoto, these institutional failures are rarely discussed in commemorative coverage of the Aum Affair. In this sense, self-critique by media and state institutions regarding their handling of the Aum Affair has been selective and self-serving, insofar as it has contained institutional failures to this one instance, and has circumvented discussions about deeper, underlying problems within these institutions.

Furthermore, the predominant characterisation of Matsumoto as a case of false accusation has meant that experiences of other victims and survivors have received less attention. Novelist Murakami Haruki's interviews with victims of the Tokyo subway attack, for instance, pose the central question, "what actually happened in the Tokyo subway the morning of 20 March, 1995?" (Murakami 2003: 196, italics in original). Despite his attentiveness to the experiences of Tokyo's victims, the Matsumoto attack is a blindspot in his attempt to understand the Aum Affair. Nevertheless, the intense focus on Kōno as the protagonist of this trauma drama has meant that Kōno was able to establish a new career as a prolific public speaker and campaigner for victims' rights. Over the past two decades, he has spoken on topics ranging from his own

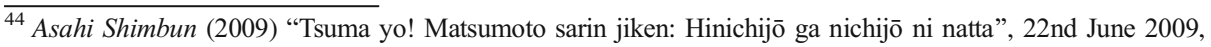
p.17. 
experiences as a suspect and the need for a public system to support crime victims to issues relating to medical care for his wife (Kōno 2015). He has also taken on several public positions, such as the Public Security Commissioner for the Nagano Prefectural Police, and a consultant for a charity that supports traumatised victims of crime and natural disasters. Kōno has also rebuked discriminatory practices employed by security authorities and members of the public against Aum believers, many of whom decided to stay even after the arrests of the leadership (Kōno 2008). Unlike many other victims who are vehemently opposed to Aum and its successor groups, he has been on amicable terms with some of its members, going as far as befriending a former believer who served a sentence for building the truck used in the Matsumoto attack (Ibid.). As Kōno explained, he believes people should be judged by their character, not external labels; as the former believer had already paid his dues by serving in prison, Kōno bore no ill will against him (Kōno 2015).

\section{Conclusions}

This article has proposed the theoretical utility of a distinction between fact-finders and narrators and has highlighted the crucial role fact-finders play in elucidating the facts of a case in the construction of cultural trauma. Information such as casualty tolls, knowledge of perpetrators' identity, modus operandi, and motives all contribute towards the construction of a coherent and persuasive trauma narrative, which narrators do not necessarily have the professional capability or authority to discover. Fact-finders may play a secondary role in directly addressing the public regarding the moral significance of events but nonetheless provide the essential empirical basis to trauma discourse. Of course, the extent of involvement by factfinders is contextual. For instance, in the case of terrorist attacks, their modus operandi-from bombings and mass shootings to running over pedestrians - may mean that narrators are able to perceive and condemn events as cultural traumas in a relatively straightforward manner. Nevertheless, fact-finders such as the police still play a role in classifying and declaring events as "terrorist attacks", not to mention going after suspects. As the Matsumoto example shows, when fact-finders do not recognise the event as being a terrorist attack, even when there is a massive number of casualties, the public recognition that the event has been "traumatic" remains underdeveloped.

Substantively, the Matsumoto investigation exposed fundamental weaknesses inherent within Japanese public institutions. The police's reliance on extracting confessions, sometimes through harsh interrogation, has been associated with exceptionally high conviction rates among developed countries but has also resulted in a number of cases of miscarriages of justice when confessions were obtained under duress. Institutional reform has been slow, with the compulsory video recording of police interviews brought into law in 2016. The Matsumoto case, as well as the police investigation following the Tokyo attack, also revealed media outlets' inability or reluctance to hold state powers accountable. During the intense media coverage of Aum Shinrikyō from 1995 onwards, few media organisations explicitly challenged illegal actions and civil rights violations by state authorities against Aum members. Though Matsumoto provided an opportunity for the press to reconsider its collusive relations with the state, the media largely carried on as before without major institutional reform. In fact, political constraints to the media have intensified since the mid-1990s following the rise of right-wing movements, exemplified by revisionist calls for "patriotic" history textbooks (Hashimoto 2015; Seaton 2007). Such movements, combined with the second Abe government's (2012-) harassment and intimidation of media institutions over critical coverage of government policy and 
discussions deemed "unpatriotic", have contributed to a deterioration of press freedom in recent years. The 2017 Press Freedom Index places Japan at 72 out of 180; Japan has consistently ranked low among developed countries (Reporters without Borders 2018). This arguably explains why news media have been keen to single out "perpetrators" seen to be located outside of the Japanese moral community such as Kōno and Aum, while the media's pursuit of scandals related to the state or elites - the Fukushima nuclear disaster chief among them - has been lacklustre. Consequently, the current discursive climate seems to privilege claims to collective trauma and victimhood, while stymieing symbolic identification of the Japanese nation or state as perpetrators of cultural traumas inflicted domestically and internationally.

Looking beyond contemporary Japan, this article has suggested that cultural trauma theory and collective memory studies more broadly could benefit from a greater attentiveness to fact-finding processes. For example, a potential avenue of enquiry may be to clarify the extent to which emergency services and relief workers play a role in the initial assessment of the severity of incidents. Similarly, scientific experts such as forensic scientists, meteorologists, and seismologists may play an important role in categorising and coding events as they locate the causes of the phenomena, categorise their size and scale, and compare them against similar historical examples: who declares a phenomenon as a natural or manmade "disaster"? How does a weather phenomenon get categorised, and given an identity through naming, as it evolves from a "weather system" to a "tropical storm", and finally a "hurricane"? What was the earthquake's magnitude, and where was its epicentre? How does a natural disaster or crime compare to previous instances? While still retaining the core insight of cultural sociology, namely its sensitivity to symbolic aspects of social life, such an approach would extend the scope of collective memory research to occupational cultures and practices of expert professions.

It is also possible to explore how technological developments change the ways trauma narratives are told. New technologies enable narrators to present and disseminate visual representations of horrific events more quickly and farther than ever before. Video footage of violence, captured through mobile phones, CCTV cameras, and police dash-cams and bodycams, can be uploaded to social media and news websites within hours, if not minutes, after an incident takes place. These videos are then sorted through algorithms, tagged with hashtags, and shared among global audiences. These videos may require expert and independent verification (for example, that the footage is actually from the event it purports to describe, or that it has not been edited to give a misleading impression), and thus assures the role of factfinders to an extent. However, it seems undeniable that many ordinary individuals without expert knowledge or socio-cultural prestige can now enter public discourse to voice their experiences and opinions more easily through the use of social media. An STS-informed approach may help to clarify how technology changes the ways in which trauma narratives take shape through social media and beyond.

Finally, there remains a question of whether cultural traumas can be wholly imagined or fictitious, in the absence of credible facts. This paper has suggested that although there may be exceptional instances of imagined trauma, claims to cultural trauma are likely to be challenged and discredited without a modicum of reliable evidence. Hence, when President Donald Trump's Counsellor Kellyanne Conway alluded to the non-existent "Bowling Green Massacre" as a justification for the travel ban from Muslim-majority countries in January 2017, her comments received universal ridicule and condemnation (Smith 2017). Fictitious "alternative facts" do not lend themselves easily to trauma narration. Unfortunately, fictitious traumas do seem to propagate at times when fact-finders fail to function and thrive in cultures in which fear of the cultural "Other" trumps the demand for accuracy, as the massacre of ethnic Koreans in Japan following the 
1923 Great Kanto Earthquake demonstrates. Following a magnitude 7.9 earthquake which flattened much of Tokyo and its surrounding areas, there were widespread false rumours that ethnic Koreans had been seen carrying bombs and had poisoned the well water. This imagined trauma of Koreans attacking the Japanese, arguably magnified by Japanese public anxieties of Korean uprising and retribution in the context of the colonization of the Korean Peninsula, resulted in the massacre of more than 6000 Koreans at the hands of vigilante mobs and public authorities (Ryang 2003). In this case, the real devastation of the earthquake led to an entirely fabricated cultural trauma of Koreans attacking Japan, ending in a bloodbath and further victimisation of a subjugated minority population. There are many differences between the false rumours in Tokyo and Conway's remarks, but a stark point of contrast lies in the response of the fact-finders. Whereas experts unanimously refuted Conway's remarks as erroneous, the aftermath of the Kanto Earthquake saw the police actively encourage violence against Koreans on the basis of mere rumour amidst the total breakdown of social order (Ibid.). In this sense, the role of fact-finders becomes ever more important in the case of fabricated traumas, as they have the authority to credit trauma narratives as real or discredit them as "fake news"; as such, they possess the capacity to steer the direction of emerging fictitious trauma narratives and their consequences.

Acknowledgements An earlier version of this paper was presented at the British Sociological Association Annual Conference 2016 at Aston University. I would like to thank David Inglis and Ian Reader in particular for helpful comments on earlier versions of this paper.

Funding The author has received funding from the Cambridge University Commonwealth, European and International Trust (Cambridge International Scholarship), and the British Academy (Postdoctoral Fellowship, Grant ID pf170054). The author also received additional funding from the Department of Sociology, University of Cambridge and Trinity Hall, University of Cambridge for fieldwork.

\section{Compliance with Ethical Standards}

Ethical Approval All procedures performed in studies involving human participants were in accordance with the ethical standards of the institutional and/or national research committee and with the 1964 Helsinki declaration and its later amendments or comparable ethical standards.

Informed Consent Informed consent was obtained from all individual participants included in the study. Additional informed consent was obtained from all individual participants for whom identifying information is included in this article.

Open Access This article is distributed under the terms of the Creative Commons Attribution 4.0 International License (http://creativecommons.org/licenses/by/4.0/), which permits unrestricted use, distribution, and reproduction in any medium, provided you give appropriate credit to the original author(s) and the source, provide a link to the Creative Commons license, and indicate if changes were made.

\section{References}

Alexander, J. C. (2003). The meanings of social life: a cultural sociology. Oxford: Oxford University Press.

Alexander, J. C. (2004a). On the construction of moral universals: the "holocaust" from war crime to trauma drama. In J. C. Alexander et al., Cultural trauma and collective identity (pp. 196-263). Berkeley: University of California Press.

Alexander, J. C. (2004b). Towards a theory of cultural trauma. In J. C. Alexander et al., Cultural trauma and collective identity (pp. 1-30). Berkeley: University of California Press.

Alexander, J. C., \& Smith, P. (2003). The strong program in cultural theory. In J. C. Alexander (Ed.), The meanings of social life (pp. 11-26). Oxford: Oxford University Press.

Baert, P. (2015). The existentialist moment: the rise of Sartre as a public intellectual. Cambridge: Polity. 
Baffelli, E., \& Reader, I. (2012). Editors' introduction. Impact and ramifications: the aftermath of the Aum Affair in the Japanese religious context. Japanese Journal of Religious Studies, 39(1), 1-28.

Bartmanski, D., \& Eyerman, R. (2011). The worst was the silence: the unfinished drama of the Katyn Massacre. In R. Eyerman, J. C. Alexander, \& E. B. Breese (Eds.), Narrating trauma: on the impact of collective suffering (pp. 237-266). Boulder, CO: Paradigm.

Bloor, D. (1991). Knowledge and social imagery. Chicago: University of Chicago Press.

Cole, S. A. (2001). Suspect identities: a history of fingerprinting and criminal identification. Cambridge, MA: Harvard University Press.

Conway, B. (2010). New directions in the sociology of collective memory and commemoration. Sociol Compass, 4(7), 442-453. https://doi.org/10.1111/j.1751-9020.2010.00300.x.

Douglas, J. (1967). The social meanings of suicide. Princeton, N.J: Princeton University Press.

Douillet, A.-C., \& Dumoulin, L. (2015). Actor network theory and CCTV development. In D. Robert \& M. Dufresne (Eds.), Actor-network theory and crime studies: explorations in science and technology (pp. 2136). Burlington: Ashgate.

Durkheim, E. (2002). Suicide: a study in sociology. London: Routledge.

Erikson, K. (1976). Everything in its path: Destruction of community in the Buffalo Creek flood. New York: Simon and Schuster.

Eyerman, R. (2001). Cultural trauma: slavery and the formation of African American identity. Cambridge: Cambridge University Press.

Eyerman, R. (2011). The cultural sociology of political assassination: from MLK and RFK to Fortuyn and Van Gogh. Basingstoke: Palgrave Macmillan.

Eyerman, R. (2015). Is this America? Katrina as cultural trauma (p. 2015). Austin: University of Texas Press.

Gao, R. (2011). Revolutionary trauma and representations of the war: the case of China in Mao's era. In R. Eyerman, J. C. Alexander, \& E. B. Breese (Eds.), Narrating trauma: on the impact of collective suffering (pp. 53-80). Boulder, CO: Paradigm Publishers.

Gardner, R. A. (1999). Lost in the cosmos and the need to know. Monum Nippon, 54(2), 217-246.

Hardacre, H. (2007). Aum Shinrikyô and the Japanese media: the pied piper meets the lamb of god. Hist Relig, 47(2/3), 171-204. https://doi.org/10.1086/524209.

Hashimoto, A. (2015). The long defeat: cultural trauma, memory, and identity in Japan. Oxford: Oxford University Press.

Hayakawa, K., \& Kawamura, K. (2005). Watashi ni totte Oumu towa nandattanoka. Tokyo: Popurasha.

Hersey, J. (1946). Hiroshima. London: Penguin.

Hirano, N. (2011). Kyōhon rui kara ukagaeru kyōgaku naiyō. In N. Inoue \& S. J. R. Sentā (Eds.), Jōhō jidai no Oumu Shinrikyō (pp. 183-220). Shunjūsha: Tokyo.

Igarashi, Y. (2007). Dead bodies and living guns: the United Red Army and its deadly pursuit of revolution, 1971-1972. Japanese Studies, 27(2), 119-137. https://doi.org/10.1080/10371390701494135.

Kisala, R., \& Mullins, M. (Eds.). (2001). Religion and social crisis in Japan: understanding Japanese society through the Aum affair. Basingstoke: Palgrave.

Kōno, Y. (2001). "Giwaku” wa hareyoutomo: Matsumoto sarin jiken no hannin to sareta watashi. Tokyo: Bungei Shunjū.

Kōno, Y. (2008). Inochi aru kagiri: Matsumoto sarin jiken o koete. Tokyo: Daisan Bunmeisha.

Kōno, Y. (2015) Personal interview with Kōno Yoshiyuki. 10 April 2015, Kagoshima Pref.

Kruse, C. (2016). The social life of forensic evidence. Oakland, CA: University of California Press.

Kumai, K. (2000). Nihon no Kuroi Natsu: Enzai [DVD]. Nikkatsu.

Lanzmann, C. (2007). Shoah [DVD (4)]. Eureka Entertainment.

Latour, B. (1993). We have never been modern. Cambridge, MA: Harvard University Press.

Latour, B. (2005). Reassembling the social an introduction to actor-network-theory. Oxford; New York: Oxford University Press.

Latour, B., \& Woolgar, S. (1986). Laboratory life: the construction of scientific facts. Princeton, N.J: Princeton University Press.

Lusher, A. (2017). As MH370 conspiracy theories continue to swirl, why has compelling new evidence not revived the search. Retrieved October 2, 2017, from http://www.independent.co. uk/news/world/australasia/mh370-missing-malaysia-airlines-plane-latest-new-evidence-developmentconspiracy-theories-what-a7703531.html.

Murakami, H. (2003). Underground: the Tokyo gas attack and the Japanese psyche. London: Vintage.

NHK Supesharu Shuzaihan. (2013). Mikaiketsu jiken, Ōmu Shinrikyō hiroku. Tōkyō: Bungei Shunjū.

Noda, N. (2010). Kakumei ka sensō ka: Oumu wa gurōbaru shihon shugi eno keishō datta. Tokyo: Saizō.

Pendleton, M. (2009). Mourning as global politics: embodied grief and activism in post-Aum Tokyo. Asian Studies Review, 33(3), 333-345.

Reader, I. (2000). Religious violence in contemporary Japan: the case of Aum Shinrikyō. Richmond: Curzon. 
Renard, B. (2015). The relevance of actor-network theory (ANT) for research on the use of genetic analysis for identification in criminal justice. In D. Robert \& M. Dufresne (Eds.), Actor-network theory and crime studies (pp. 113-126). Burlington: Ashgate.

Reporters Without Borders (2018). 2017 World Press Freedom Index Retrieved January 2018, from https://rsf. org/en/ranking_table.

Robert, D., \& Dufresne, M. (2015). The factishes of DNA identification: how a scientist speaks about his craft to politicians. In D. Robert \& M. Dufresne (Eds.), Actor-network theory and crime studies: explorations in science and technology. Burlington: Ashgate.

Ryang, S. (2003). The great Kanto earthquake and the massacre of Koreans in 1923: notes on Japan's modern national sovereignty. Anthropol Q, 76(4), 731-748.

Saito, H. (2006). Reiterated commemoration: Hiroshima as national trauma. Sociological Theory, 24(4), 353-376.

Seaton, P. (2007). Japan's contested war memories: the "memory rifts" in historical consciousness of World War II. London; New York: Routledge.

Shimada, H. (2012). Oumu Shinrikyō Jiken (Vol. 1-2). Tokyo: Toransubyū.

Shimazono, S. (1995). In the wake of Aum: the formation and transformation of a universe of belief. Japanese Journal of Religious Studies, 22(3/4), 381-415.

Smith, D. (2017). Kellyanne Conway's fictitious "Bowling Green massacre" not a one-time slip of the tongue. Retrieved May 11, 2017, from https:/www.theguardian.com/us-news/2017/feb/06/kellyanne-conway-fakebowling-green-massacre-three-times.

Sztompka, P. (2004). The trauma of social change: a case of postcommunist societies. In J. C. Alexander et al., Cultural trauma and collective identity (pp. 155-195). Berkeley: University of California Press.

Tsuji, R. (2011). Oumu Shinrikyō to inbō ron. In N. Inoue \& S. J. R. Sentā (Eds.), Jōhō jidai no Oumu Shinrikyō (pp. 360-384). Shunjūsha: Tokyo.

Tsukada, H. (2011). Shinritō no undō tenkai to katsudō naiyō. In N. Inoue \& S. J. R. Sentā (Eds.), Jōhō jidai no Oumu Shinrikyō (pp. 307-327). Shunjūsha: Tokyo.

Ushiyama, R., \& Baert, P. (2016). Cultural trauma, counter-narratives, and dialogical intellectuals: the works of Murakami Haruki and Mori Tatsuya in the context of the Aum affair. Theory and Society, 45(6), 471-499. https://doi.org/10.1007/s11186-016-9279-6.

Yang, J. (2012). Tombstone: the untold story of Mao's great famine. London: Allen Lane. 